\title{
Traditional Game As a Way for Healthy in Bajo's Children
}

\section{Nani Restati Siregar ${ }^{1}$ and Muhammad IIham²}

${ }^{1}$ Department of Psychology, Faculty of Psychology Universitas Gadjah Mada, Jl. Sosiohumaniora, Bulaksumur, Yogyakarta, 55281, Indonesia

${ }^{2}$ Faculty of Teacher Training, Universitas Halu Oleo, Jl. H. A. E. Mokodompit, Anduonuhu, Kendari, 93111. Indonesia

\section{Abstract}

Traditional games for children who live in urban areas was a significant activity. That was involved much physical activity and influenced psychological development in children. Generally, the traditional games were found in the low-income community and large area. The qualitative study described in this paper aimed to: (i) explore parents view about playing for their children; (ii) explore teachers view about academically benefit of the traditional game for students. Semi-structured, in depth-interviews, were interviewed conducted with two parents of Bajo' Tribe and three teachers of the

Corresponding Author: Nani Restati Siregar nanirestatiilham@gmail.com

Received: 10 November 2018 Accepted: 6 January 2019 Published: 10 March 2019 Publishing services provided by Knowledge E

(c) Nani Restati Siregar and Muhammad llham. This article is distributed under the terms of the Creative Commons

Attribution License, which permits unrestricted use and redistribution provided that the original author and source are credited.

Selection and Peer-review under the responsibility of the UASC Life Sciences 2016 Conference Committee.
G OPEN ACCESS elementary school. The result showed that traditional games are important for children's physical and psychological health (cognition, emotion, and social aspects). Implications for future will consider local wisdom based-curriculum in kindergarten and elementary school. Traditional games are important for student's psychological health, as well as physical health.

Keywords: Bajo's Children, Cognition, Emotion, Physic, Social, Playing traditional game.

\section{Introduction}

The Bajo's tribe was born and lives on the sea. It has become a part of their life, for example, fishing as income primary source for them. Most of their life happened on the sea, not only for income but also as a playground of their children. We can see children playing on the sea for different kind of games, for example swimming competition, playing ball, diving, and so forth. On the other side, children were playing on the land in front or around their home, e.g., main karet, lompat tali, balap ban, and bermain kelereng (in Indonesia). Kinds of these games were mentioned as traditional games which involved much physical activity. Traditional games are usually available played by children in the rural community due to the lower cost compared to the modern games (video games). Rural children are more likely to live in low-income families [1]. Consequently, traditional games are mostly used by children, especially in Bajo's children. 
Play can be considered as a form of behavior, which takes place according to rules in a specific space and time. Due to this feature, playing becomes the subject of study in different sciences. The interest in the study of play arises in pedagogy, psychology, sociology, ethnology, philosophy, but is also an essential segment of art, economy, and other areas. That fact confirms the importance of play as a unique phenomenon which accompanies us throughout our lives from early childhood. There are many games which are meant for a different age of groups of children and adults. Some of those are used in working with children, due to the possible effect on the improvement of a child psychophysical state. In the traditional game, the players pay attention to abiding by the rules and warn each other about certain deflections. Children are very critical and consistent in implementing specific rules. During the game, they warn each other about behavior which is not allowed. Therefore, traditional game based-school can improve the human relationships between students in class and increase of students' socialization outside classes [2]. It can be inferred that traditional games useful for children social development.

Others benefits of traditional games are the intensity of positive emotions was higher in cooperative games and lower in individual games. It can contribute to the motor, linguistic, cognitive and social-emotional development fields of children [3]. All of them are mentioned as a psychological healthy for children. Another side, traditional games as physical activity or active playing can give benefit to physical health, i.e., increase heart rate, oxygen consumption, and blood pressure. This benefit indicates a potential role of playing strategies for cardiovascular health in children [4]. All of the benefits of traditional games mentioned are not only for psychological health but also for physical health for children.

This recent study focused on the traditional games being specific to Bajo's children, with objectives:

(i) Bajo's community are on medium and low social, economic status (SES). Moreover, play a traditional game is a way to develop child ability on thinking and emotion as well as socialization between children, as well as physical health.

(ii) Understand how parents believed that traditional games could benefit their children in psychological and physical health.

(iii) Children playing traditional games were not only outside the school but also in the schoolyard. Therefore, the research explored the teachers' perception of traditional games in Bajo's Tribe and how if traditional games would be adapted as part of a local wisdom-based curriculum for further. 
The play is considered to have many beneficial effects on the development of children's emotional health. The play is a significant part of a child and referred to as "a child work" for achieving optimal development [5]. Play in children is considered important in achieving the development of his mental health, so the play is a type of therapy in children called play therapy. Play therapy is based on two premises: (i) the child expresses his or her psychological state through play, making play a window into the child's mind, and (ii) by directing the children's play, the therapist can help resolve a child's conflicts.

Traditional games were identified into $[6,7]$.

(i) Psychomotor Games, i.e., games that require the movement to play but does not show in the communication between the players. For example, yoyo, jump, and kite.

(ii) The cooperation game, a game that requires cooperation among the players with others. For example, the circle game, jump rope, dancing together, or games that need a chorus of mutual sounds.

(iii) The games have opponents:

(a) One of the opponents of all, a player must capture the other players.

(b) One by one, that is, resistance against each other. It can be divided into (1) the resistance of the symmetrical, such as wrestling, fighting with sticks, each kicking a ball, throw and catch the ball. (2) resistance is not symmetrical, for example, poncho.

(c) All against all, which is the resistance between all players. For example, scramble the ball sack racing.

(iv) Game co. - resistance consists of:

(a) The opposite team is a team to the resistance between the two teams.

(b) One against all

(c) All against all

(d) The game was ambivalent that all players could be a friend or rival without any clear criteria.

Based on the description of the classification of traditional games, we can conclude that the four classifications of the game focus on movement or physical activity. 


\section{Methods}

In this qualitative research in which data is collected through depth interviews by participants. Participants consist of three teachers and two parents. They are asked comments about the traditional game each other, for parents described what they believe of the traditional game for healthy children. Some questions are: "what kind of games you know from your environment which your children played?"; "What do you know about the advantages of playing the game for your children?" Then, three teachers in the elementary school asked for answers some questions are related traditional games which are played by students in the school. Those questions are: "what your opinion about children played games?"; "is there special anything from playing the game?"; "What is your suggestion to the government from children playing the game in school?". Researchers develop all questions.

\section{Results}

From depth interviews, in traditional games, much information could be reached about the kind of games and their functions to psychological and physical health. The distribution of content features in traditional games according to teachers and parents are presented in Table 1.

TABLE 1: The distribution of content features in traditional games according to the parents and teachers.

Kinds of game
Marbels
Main Yeye
Lompat Tali
Main Kengkeng
Enggo sembunyi
Diving
Swimming
Throwing the ball on the
sea

\begin{tabular}{|c|c|c|c|}
\hline \multicolumn{4}{|c|}{ Age of Development/Healthy } \\
\hline Cognitive & Emotion & Social & Physic \\
\hline$*$ & $*$ & $*$ & - \\
\hline$*$ & $*$ & $*$ & $*$ \\
\hline$*$ & $*$ & $*$ & $*$ \\
\hline$*$ & $*$ & $*$ & $*$ \\
\hline$*$ & $*$ & $*$ & - \\
\hline$*$ & $*$ & $*$ & $*$ \\
\hline$*$ & $*$ & $*$ & $*$ \\
\hline & $*$ & $*$ & $*$ \\
\hline
\end{tabular}

It is seen that in Table 1, the content features in games are all of them involves cognitive, emotion, and social aspect as psychological health. Some of the games are not enough involves many physical activities. The symbol (-) means physical activity is not higher than a traditional game in the symbol $\left(^{*}\right)$. 
According the parents are the traditional game can improve memory, happy together with others, meet many friends and to health physically their children. They had believed the game as a heritage from their ancestors. Furthermore, according to the teachers are the game benefits to the students in many areas; they can be social with others, happy and they can create a strategy for win the game. Surely, a traditional game which involves physical activity may be healthy for children (students). Moreover, also, the teachers answer that traditional games most essential to be included in the curriculum, especially for elementary school student (and kindergarten, too).

\section{Discussion}

Meaningful cross-cultural research is increasingly common today, fortunately, supported by a growing number of developmental scientists who grew up outside North America, and the urgent need to recognize and study more diverse groups within and outside the United States is universally recognized

This study explorative had found that traditional game in Bajo's children plays an important role in health psychology and physic. The parents and teachers have the same opinion; they consider it necessary for healthy childhood development. For example, traditional game intervention can improve motor skills for children school age [8]. Motor skills are needing to physic activity, e.g., for sport, playing, and so forth.

Traditional games should not only for children played but also support from parents. Other Study had found that children aged $2 \mathrm{yr}$ to $17 \mathrm{yr}$ found that there are play activities with the children of parents who have had a positive impact on the physical health of children, among other things: walking and exercising together. Also, the togetherness of the child with the parents in exercising a positive influence on emotional health, i.e., children become excited and feel warm with his parents [9]. Parents involved in traditional games are many benefits for their children, one of them is close up the relation between child and parent.

Furthermore, traditional games are necessary to include in the pre-school and primary school curriculum, especially children from rural and not advantage economically. It benefits for the welfare of children and adolescents [10]. A traditional game which is involving physic activity, it can be improved through environmental-based. It has been researched about environmental factors, i.e., home and neighbors who support children social development [11]. Furthermore, the social-ecological model describes the development of physical activity in the context of the environment in homes and schools. An 
ecological version of information processing illustrates the importance of viewing knowledge and technique dimensions of gameplay as interdependent. Bronfenbrenner's [12] ecological theory was said that environmental factors (ecology) play an important role in life-span development, particularly for the development of children through play. Bronfenbrenner said that there are five levels or system contained in the environment, among others: microsystem, mesosystem, exosystem, and macrosystem and chronosystem. In this traditional game played by Bajo's children, include games made by children in the environment around the home and school environment is referred to as the environment microsystem. Children gain experience with friends as well as the involvement of parents and other adults in the second environment the play. These experiences give impact on the development of cognitive, emotional and social as well as achieving physical health, due to traditional games involve physical activity.

The study is preliminary and necessary to follow up by further research using extend participants, primarily for children played the game as the participants. We want to know how they feel while playing the game together with their friends.

\section{Conclusions}

Traditional games do not only give benefits for psychological health but also physically healthy for children played the game. The game is needed to be extended in school as a curriculum at school.

\section{References}

[1] U.S. Department of Health and Human Services Health Resources and Services Administration. The health and well-being of children in rural areas: A portrait of the nation 2007. Department of Health and Human Services, Rockville, Maryland: U.S; 2011. p. 1-52. https://mchb.hrsa.gov/nsch/07rural/moreinfo/pdf/nsch07rural.pdf

[2] Kovačević T, Opić S. Contribution of traditional games the quality of students' relations and frequency of students' socialization in primary education. Croation Journal of Education, 2014;16(1):95-112. https://hrcak.srce.hr/file/174035

[3] Gelisli Y, Yazici E. A study into traditional child games played in Konya region in terms of development fields of children. Elsevier Procedia-Social and Behavioral Sciences 2015;197:1859-1865. https://www.sciencedirect.com/science/article/ pii/S1877042815042482 
[4] Rauber SB, Boullosa DA, Carvalho FO, de Moraes JFVN, de Sousa IRC, Simues HG, Campbell CSG. Traditional games resulted in post-exercise hypotension and a lower cardiovascular response to the cold pressor test in healthy children. Frontiers in Psychology 2014;5(235):1-7. https://www.ncbi.nlm.nih.gov/pmc/articles/ PMC4069719/

[5] Lamb ME. Processes underlying social, emotional, and personality development. In: Handbook of child psychology and developmental science (cognitive process). Lerner, Lynn,Ulrich (Eds). John Wiley \& Sons, Inc. New Jersey;2015.p. 1-10 https: //www.wiley.com/en-us/Handbook+of+Child+Psychology+and+Developmental+ Science\%2C+7th+Edition-p-9781118136850

[6] Iswinarti. Pengaruh permainan tradisional melalui metode experiental learning terhadap kompetensi social anak usia sekolah. [The Influence of traditional games through the experiental learning method for children]. Disertasi.. Fakultas Psikologi. Universitas Gadjah Mada. Yogjakarta; 2005 \{in Bahasa Indonesia] http://etd.repository.ugm.ac.id/index.php?mod=penelitian_detail\&sub= PenelitianDetail\&act=view\&typ=html\&buku_id=88268\&obyek_id=4

[7] Lavega P, Alonso JL, Etsebeste J, Lagardera F, March J. Relationship between traditional games and the intensity of emotion experienced by participants. Res. $Q$ Exerc Sport 2014;85(4):457-467. https://www.ncbi.nlm.nih.gov/pubmed/25412128

[8] Gipit C, Abdullah MA, Musa MR, Kosai NA, Maliki AB. The effect of traditional games intervention programme in the enhancement school-age children's motor skills. A Pleminary Study, Health, movement \& Exercise 2017;6(2):157-169. https: //www.mohejournal.com/index.php/mohe/article/view/MoHE\%20Vol6\%282\%29_13

[9] Berntsson LT, Ringsberg KC. Swedish Parents' activities together with their children and children's health: a study of children aged 2-17 years. Scand. J. Public Health 2014;(42):41-51. https://www.ncbi.nlm.nih.gov/pubmed/25416573

[10] Stalsberg R, Pederson AV. Effect of socioeconomic status on the physical activity in adolescents: a systematic review of the evidence. Scand. J. Med. Sci. Sports 2010;20(3):368-383. https://www.ncbi.nlm.nih.gov/pubmed/20136763

[11] Suen $Y N$, Cerin E, Huang Yj, Mellecker RR. Measures of environmental correlates of physical activity for urban chinnese preschool-aged children: Development and Reliability 2015;5(3):1-8. http://journals.sagepub.com/doi/abs/10.1177/ 2158244015604690

[12] Santrock JW. A topical approach to Life span development. Seventh edition. MacGraw- Hill. New York;2014. p. 27-28. https://trove.nla.gov.au/work/ 7412141 ?q\&sort=holdings+desc\&_=1524471175430\&versionld=207917760 